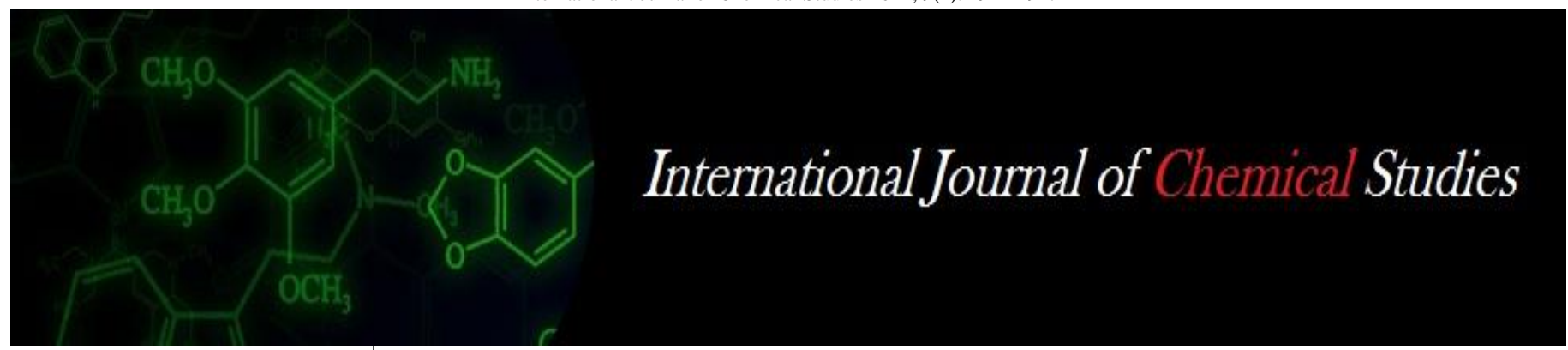

P-ISSN: 2349-8528

E-ISSN: 2321-4902

www.chemijournal.com

IJCS 2021; 9(1): 2944-2947

(C) 2021 IJCS

Received: 22-11-2020

Accepted: 30-12-2020

\section{Himalay Sahu}

Department of Agronomy,

College of Agriculture, Indira

Gandhi Krishi Vishwavidyalaya,

Raipur, Chhattisgarh, India

Nitish Tiwari

Department of Agronomy, College of Agriculture, Indira Gandhi Krishi Vishwavidyalaya,

Raipur, Chhattisgarh, India

\section{Influence of different herbicides on weed flora of Berseem (Trifolium alexandrinum L.)}

\author{
Himalay Sahu and Nitish Tiwari
}

DOI: https://doi.org/10.22271/chemi.2021.v9.i1ao.11677

\begin{abstract}
A field experiment was conducted at Research cum Instructional Farm, IGKV, Raipur (C.G.) during rabi 2019-20 to know the influence of different herbicides on weed flora of berseem (Trifolium alexandrinum L.). The experiment was laid out in a Randomized Block Design with three replications of ten treatments viz. pendimethalin (PE) $1000 \mathrm{~g} / \mathrm{ha}\left(\mathrm{T}_{1}\right)$, pendimethalin $(\mathrm{EPoE})$ at $10 \mathrm{DAS} 1000 \mathrm{~g} / \mathrm{ha}\left(\mathrm{T}_{2}\right)$, oxyfluorfen (PE) $250 \mathrm{~g} / \mathrm{ha}\left(\mathrm{T}_{3}\right)$ imazethapyr (PoE) $40 \mathrm{~g} / \mathrm{ha}$ just after $1^{\text {st }}$ cutting $\left(\mathrm{T}_{4}\right)$, imazethapyr (PoE) $40 \mathrm{~g} / \mathrm{ha}$ just after $2^{\text {nd }}$ cutting $\left(\mathrm{T}_{5}\right)$, imazethapyr $(\mathrm{PoE}) 40 \mathrm{~g} / \mathrm{ha}$ just after $1^{\text {st }}$ and $2^{\text {nd }}$ cutting $\left(\mathrm{T}_{6}\right)$, imazamox $35 \%+$ imazethapyr 35\% (ready mix) (PoE) $70 \mathrm{~g} /$ ha just after $1^{\text {st }}$ cutting $\left(\mathrm{T}_{7}\right)$, imazamox $35 \%+$ imazethapyr $35 \%$ (ready mix) (PoE) $70 \mathrm{~g} /$ ha just after $2^{\text {nd }}$ cutting $\left(\mathrm{T}_{8}\right)$, sodium acifluorfen $16.5 \%+$ clodinafoppropargyl 8\% (ready mix) (PoE) $187.5 \mathrm{~g} /$ ha just after $1^{\text {st }}$ cutting $\left(\mathrm{T}_{9}\right)$ and control $\left(\mathrm{T}_{10}\right)$. The soil of experimental field was clayey in texture and slightly alkaline with $(\mathrm{pH} 7.4)$ in reaction. The amount of available N, P and $\mathrm{K}$ were low, medium and high respectively. Among these treatments, at 20 DAS and before $1^{\text {st }}$ cutting of berseem the density and dry weight of weeds were found significantly lowest under the treatment oxyfluorfen $250 \mathrm{~g} / \mathrm{ha}$ applied as PE $\left(\mathrm{T}_{3}\right)$. However, before $2^{\text {nd }}$ cutting and at harvest of berseem the density and dry weight of weeds were found significantly lowest under sodium acifluorfen $16.5 \%$ + clodinafop-propargyl $8 \%$ as PoE applied just after $1^{\text {st }}$ cutting $\left(\mathrm{T}_{9}\right)$. With regards to total weed density it was found at par with the PE application of oxyfluorfen $250 \mathrm{~g} / \mathrm{ha}\left(\mathrm{T}_{3}\right)$. But it was also found phytotoxic effect on berseem crop up to 15-20 DAA, hence negative impact on the growth and yield of berseem plants was observed.
\end{abstract}

Keywords: Berseem, herbicide, phytotoxic, oxyfluorfen, sodium acifluorfen $16.5 \%$ + clodinafoppropargyl $8 \%$

\section{Introduction}

Berseem (Trifolium alexandrinum L.) is India's most dominant winter season forage crop with a productivity of 60-110 t/ha in 1.9 mha area (Anonymous, 2012) ${ }^{[2]}$. It is not a crop of Chhattisgarh but getting popularity among the farmers because it offers high quality, proteinrich green forage (15-25\%), minerals (11-19\%) and carotene (Sharma and Murdia, 1974) ${ }^{[7]}$.

Even Berseem suffers from strong crop weed competition at initial 30-40 DAS, or at times up to $1^{\text {st }}$ cutting. Fodder yield and seed yield losses have been estimated to be 23-30 per cent and 50 percent, respectively due to weeds (Joshi and Bhilare, 2006; Alfred, 2012) ${ }^{[4,1]}$. Weeds particularly Cichoroium intybus, Medicago denticulata, Trifolium flagiferum, Cyperus rotundus, Alternanthera sessilis and Chenopodium album etc., are found associated with berseem and increase computational stress by stealing vital plant nutrients, water, moisture and space (Jain, 1998) ${ }^{[3]}$. Cichoroium intybus is one of the major obnoxious weed associated with berseem crop that offer more competition for essential growth factors (Kewat et al., 2002) ${ }^{[5]}$. Conventional techniques of weed management are quite expensive, laborious and are sometimes not reliable due to labours being unavailable. In such a scenario, chemical weed control offers a decent option in contrast to conventional weeding, so testing pre and postemergence herbicides alone and in combination is a better alternative to conventional methods. Since the comparative analysis of bio-efficiency of different weed control practices in berseem is available with very scarce knowledge, the present investigation is planned to reveal the appropriate herbicides for weed management in berseem.
Corresponding

Department of Agronomy, College of Agriculture, Indira Gandhi Krishi Vishwavidyalaya, Raipur, Chhattisgarh, India 


\section{Materials and Methods \\ Study Site Description}

The experiment was performed at the Research cum Instructional Farm, Indira Gandhi Krishi Vishwavidyalaya, Raipur (C.G.), during the 2019-20 rabi season. Raipur is the capital of Chhattisgarh state and is situated at $21^{0} 16^{\prime}$ North latitude and $81^{\circ} 36^{\prime}$ East longitudes at an altitude of 298.56 meters above the mean sea level.

\section{Experimental details}

The experimental soil was clayey in texture and slightly alkaline with $(\mathrm{pH} \mathrm{7.4)}$ with medium fertility having $0.63 \%$ soil organic carbon, low nitrogen (189.64 kg/ha), medium phosphorous (12.30 kg/ha) and high potassium (257.60 kg/ha) content. The variety of berseem "SS-51" was line sown with a row to row distance of $20 \mathrm{~cm}$ by seed drill on $29^{\text {th }}$ November, 2019 and harvested on $3^{\text {rd }}$ May, 2020. The experiment was laid out in a Randomized Block Design with three replications of ten treatments viz. pendimethalin (PE) $1000 \mathrm{~g} / \mathrm{ha}\left(\mathrm{T}_{1}\right)$, pendimethalin (EPoE) at 10 DAS $1000 \mathrm{~g} / \mathrm{ha}\left(\mathrm{T}_{2}\right)$, oxyfluorfen (PE) $250 \mathrm{~g} / \mathrm{ha}\left(\mathrm{T}_{3}\right)$ imazethapyr $(\mathrm{PoE}) 40 \mathrm{~g} / \mathrm{ha}$ just after $1^{\text {st }}$ cutting $\left(\mathrm{T}_{4}\right)$, imazethapyr (PoE) $40 \mathrm{~g} /$ ha just after $2^{\text {nd }}$ cutting $\left(\mathrm{T}_{5}\right)$, imazethapyr $(\mathrm{PoE}) 40 \mathrm{~g} / \mathrm{ha}$ just after $1^{\text {st }}$ cutting $f b$ imazethapyr (PoE) $40 \mathrm{~g} / \mathrm{ha}$ just after $2^{\text {nd }}$ cutting $\left(\mathrm{T}_{6}\right)$, imazamox 35\% + imazethapyr 35\% (ready mix) (PoE) 70 $\mathrm{g} /$ ha just after $1^{\text {st }}$ cutting $\left(\mathrm{T}_{7}\right)$, imazamox $35 \%+$ imazethapyr $35 \%$ (ready mix) (PoE) $70 \mathrm{~g} / \mathrm{ha}$ just after $2^{\text {nd }}$ cutting $\left(\mathrm{T}_{8}\right)$, sodium acifluorfen $16.5 \%$ + clodinafop-propargyl $8 \%$ (ready mix) (PoE) $187.5 \mathrm{~g} /$ ha just after $1^{\text {st }}$ cutting $\left(\mathrm{T}_{9}\right)$ and control $\left(\mathrm{T}_{10}\right)$.

\section{Cultivation details}

"Berseem seeds@25 kg/ha was sown 2-3 cm deep while maintaining $20 \mathrm{~cm}$ row to row spacing by seed drill on 29 November 2019. In order to maintain uniform plant population in all the treatments gap filling was done at 10 DAS. The first cutting was done at 55 DAS and subsequent two cuttings were made at 30 days after first cutting. Cutting was done with the help of sickle manually at $5 \mathrm{~cm}$ above ground level. After the $3^{\text {rd }}$ cut, the rejuvenated crop was left for seed growth and final harvesting was done at 155 DAS ( 3 May 2020). Herbicides namely, pendimethalin, oxyfluorfen, imazethapyr, imazamox 35\% + imazethapyr 35\% (ready mix), and sodium acifluorfen $16.5 \%$ + clodinafop-propargyl $8 \%$ (ready mix) were sprayed as per treatments. The dosage of various herbicides provided under each treatment was determined by the active ingredient present in the commercial products. Before spraying, the weighed amount of herbicide and water for each plot was thoroughly mixed in the bucket and later sprayed uniformly in the plot using a flat-fan nozzle with the help of a knapsack sprayer. Every time, fresh solution was prepared separately for individual treatment. Once all three replications of a treatment were sprayed with their respective herbicide, the sprayer was washed properly with detergent and eventually rinsed with fresh water before adding other herbicides. At the time of application of the herbicide all precautions were taken into consideration.

\section{Observations recorded}

The data on weed density and dry weight were recorded with the help of a quadrate $\left(0.25 \mathrm{~m}^{2}\right)$ at four places randomly chosen and then expressed in number per square meter and gram per square meter. The weed control efficiency (WCE) was worked out on the basis of weed dry matter recorded in each treatment at $20 \mathrm{DAS}$, before $1^{\text {st }}$ cut $(55 \mathrm{DAS})$, before $2^{\text {nd }}$ cut (85 DAS) and at harvest (155 DAS) by using the formula suggested by Mani et al., $1973^{[6]}$.

$\mathrm{WCE}(\%)=\frac{D M c-D M t}{D M c} \times 100$

Where, DMc $=$ Dry matter of weeds in the in the unweeded check (control), DMt $=$ Dry matter of weeds in the treated plot.

Values were subjected to square root transformation $(\sqrt{x+0.5})$ prior to statistical analysis to normalize their distribution.

\section{Results and Discussion \\ Weed flora}

During the crop growth period Medicago denticulata, Cichorium intybus, Chenopodium album were found abundantly and grouped as major weeds while the density of Melilotus indica, Alternanthera sessilis, and Echinochloa colona, Physallis minima observed lesser and grouped as other weeds.

\section{Effect of different herbicides on weed density}

Weed density $/ \mathrm{m}^{2}$ in berseem was recorded at 20 DAS, before $1^{\text {st }}$ cutting (55 DAS), before $2^{\text {nd }}$ cutting ( 85 DAS) and at harvest (155 DAS) and are presented in Table 1 . Weed density was significantly influenced by various herbicidal treatments.

At 20 DAS and before $1^{\text {st }}$ cutting of berseem, the PE application of oxyfluorfen $250 \mathrm{~g} / \mathrm{ha}\left(\mathrm{T}_{3}\right)$ was superior over all the treatment as total density of weeds $\left(5.00\right.$ and $17.33 / \mathrm{m}^{2}$, respectively) were recorded lowest under this treatment. While, the total weed density was recorded highest (42.00 and $\left.81.00 / \mathrm{m}^{2}\right)$ under control $\left(\mathrm{T}_{10}\right)$. While, before $2^{\text {nd }}$ cutting and at harvest of berseem, total density of weeds (27.33 and $32.00 / \mathrm{m}^{2}$, respectively) were found significantly lowest under the PoE application of sodium acifluorfen $16.5 \%+$ clodinafop-propargyl 8\% (ready mix) (PoE) $187.5 \mathrm{~g} /$ ha just after $1^{\text {st }}$ cutting $\left(\mathrm{T}_{9}\right)$ and found at par with the PE application of oxyfluorfen $250 \mathrm{~g} / \mathrm{ha}\left(\mathrm{T}_{3}\right)$. Before $2^{\text {nd }}$ cutting highest values of total weed density $\left(117.00 / \mathrm{m}^{2}\right)$ was recorded under the PoE application of imazamox $35 \%$ + imazethapyr $35 \%$ (ready mix) $70 \mathrm{~g} /$ ha applied just after $2^{\text {nd }}$ cutting $\left(\mathrm{T}_{8}\right)$ and at harvest highest values of total weed density $\left(150.00 / \mathrm{m}^{2}\right)$ was recorded under control $\left(\mathrm{T}_{10}\right)$.

\section{Effect of different herbicides on weed dry weight}

The data on dry matter of weeds in different treatments recorded at $20 \mathrm{DAS}$, before $1^{\text {st }}$ cut $(55 \mathrm{DAS})$, before $2^{\text {nd }}$ cut (85 DAS) and at harvest (155 DAS) are presented in Table 2. At 20 DAS and before $1^{\text {st }}$ cutting of berseem, the PE application of oxyfluorfen $250 \mathrm{~g} / \mathrm{ha}\left(\mathrm{T}_{3}\right)$ was superior over all the treatment as total dry weight of weeds (3.09 and 17.53 $\mathrm{g} / \mathrm{m}^{2}$, respectively) were recorded lowest under this treatment. Followed by PE application of pendimethalin $1000 \mathrm{~g} / \mathrm{ha}\left(\mathrm{T}_{1}\right)$. While, the total weed dry weight was recorded highest (10.52 and $\left.40.59 / \mathrm{m}^{2}\right)$ under control $\left(\mathrm{T}_{10}\right)$. Before $2^{\text {nd }}$ cutting and at harvest of berseem, total dry weight of weeds (15.57 and $46.17 \mathrm{~g} / \mathrm{m}^{2}$, respectively) were found significantly lowest under the PoE application of sodium acifluorfen $16.5 \%+$ clodinafop-propargyl 8\% (ready mix) (PoE) $187.5 \mathrm{~g} / \mathrm{ha}$ just after $1^{\text {st }}$ cutting $\left(\mathrm{T}_{9}\right)$. However, highest values of total weed dry weight (106.33 and $198.03 \mathrm{~g} / \mathrm{m}^{2}$, respectively) was recorded under control $\left(\mathrm{T}_{10}\right)$. 
The selective action of oxyfluorfen, pendimethalin and imazethapyr was the reason for better control of grassy and broad-leaves weeds. That resulted in poor crop weed competition during critical crop growth period. This resulted in meagre competition of weeds to crop with respect to moisture, space, sunlight and nutrition which caused better growth and development of crop. It may be inferred that weed free environment facilitated better growth and crop development with higher berseem green forage and seed yield.

While the non-selective action of sodium acifluorfen $16.5 \%+$ clodinafop-propargyl $8 \%$ (ready mix) caused significant reduction in the density and dry matter production of weeds, the growth of berseem plants were also inhibited due to its phytotoxicity. Hence, this treatment recorded very poor green forage and seed yield.

Effect of different herbicides on Weed control efficiency Weed control efficiency (WCE) was computed at 20 DAS, before $1^{\text {st }}$ cutting (55 DAS), before $2^{\text {nd }}$ cutting ( 85 DAS) and at harvest (155 DAS) and presented in Table 3. It was evident from the data that at 20 DAS and before $1^{\text {st }}$ cutting of berseem the highest weed control efficiency $(70.66 \%$ and $56.81 \%$, respectively) was recorded under the $\mathrm{PE}$ application of oxyfluorfen $250 \mathrm{~g} / \mathrm{ha}\left(\mathrm{T}_{3}\right)$ as compared to all other treatments. It was followed by the PE application of pendimethalin 1000 $\mathrm{g} / \mathrm{ha}\left(\mathrm{T}_{1}\right)$ (51.05 and $41.41 \%$, respectively). While the lowest weed control efficiency ( $2.98 \%$ and $2.86 \%$, respectively) was recorded under sodium acifluorfen $16.5 \%$ + clodinafoppropargyl $8 \%$ (ready mix) $187.5 \mathrm{~g} / \mathrm{ha}$ applied just after $1^{\text {st }}$ cutting as $\mathrm{PoE}\left(\mathrm{T}_{9}\right)$.

Before $2^{\text {nd }}$ cutting and at harvest weed control efficiency was calculated highest $(85.36 \%$ and $76.41 \%$, respectively) under the PoE application of sodium acifluorfen $16.5 \%+$ clodinafop-propargyl $8 \%$ (ready mix) $187.5 \mathrm{~g} / \mathrm{ha}$ applied just after $1^{\text {st }}$ cutting $\left(\mathrm{T}_{9}\right)$. The non-selective action of sodium acifluorfen $16.5 \%$ + clodinafop-propargyl $8 \%$ (ready mix) $187.5 \mathrm{~g} / \mathrm{ha}$ just after $1^{\text {st }}$ cutting $\left(\mathrm{T}_{9}\right)$ was the reason for effective control of weeds so recorded highest weed control efficiency than rest of the treatments.

Table 1: Total weed density during different growth periods of berseem as influenced by different herbicidal treatments

\begin{tabular}{|c|c|c|c|c|}
\hline \multirow[b]{2}{*}{ Treatment } & \multicolumn{4}{|c|}{ Weed density (number/m²) } \\
\hline & $\begin{array}{c}\text { At } \\
\text { 20 DAS }\end{array}$ & \begin{tabular}{|c|}
$\begin{array}{c}\text { Before } 1^{\text {st }} \text { cut } \\
\text { (55 DAS) }\end{array}$ \\
\end{tabular} & $\begin{array}{c}\text { Before } 2^{\text {nd }} \text { cut } \\
\text { (85 DAS) }\end{array}$ & $\begin{array}{l}\text { AT harvest } \\
\text { (155 DAS) }\end{array}$ \\
\hline $\mathrm{T}_{1}$-Pendimethalin (PE) $1000 \mathrm{~g} / \mathrm{ha}$ & $3.98(16.33)$ & $5.98(35.33)$ & $7.88(61.67)$ & $8.67(74.67)$ \\
\hline $\mathrm{T}_{2}$ - Pendimethalin (EPoE) $1000 \mathrm{~g} / \mathrm{ha}$ at $10 \mathrm{DAS}$ & $4.81(23.67)$ & $6.62(43.34)$ & $7.72(51.67)$ & $7.71(60.33)$ \\
\hline $\mathrm{T}_{3}$-Oxyfluorfen (PE) $250 \mathrm{~g} / \mathrm{ha}$ & $2.35(5.00)$ & $4.22(17.33)$ & $5.93(34.67)$ & $6.01(35.66)$ \\
\hline T4-Imazethapyr (PoE) $40 \mathrm{~g} /$ ha just after $1^{\text {st }}$ cutting & $5.87(34.00)$ & $8.59(73.33)$ & $9.19(84.00)$ & $10.09(101.33)$ \\
\hline $\mathrm{T}_{5}$-Imazethapyr (PoE) $40 \mathrm{~g} /$ ha just after $2^{\text {nd }}$ cutting & $6.28(39.00)$ & $8.86(78.00)$ & $10.27(105.00)$ & $11.29(127.00)$ \\
\hline $\begin{array}{c}\text { T}_{6} \text {-Imazethapyr (PoE) } 40 \mathrm{~g} / \text { ha just after } 1^{\text {st }} \text { cutting } f b \text { Imazethapyr just after } 2^{\text {nd }} \\
\text { cutting }\end{array}$ & $6.10(36.67)$ & $8.67(74.67)$ & $9.08(82.00)$ & $9.08(82.00)$ \\
\hline $\begin{array}{c}\mathrm{T}_{7} \text {-Imazamox } 35 \% \text { + Imazethapyr } 35 \% \text { (ready mix) (PoE) } 70 \mathrm{~g} / \mathrm{ha} \text { just after } 1^{\text {st }} \\
\text { cutting }\end{array}$ & $5.99(35.33)$ & $8.75(76.00)$ & $9.21(84.33)$ & $9.41(88.00)$ \\
\hline $\begin{array}{c}\text { T8-Imazamox 35\% + Imazethapyr } 35 \% \text { (ready mix) (PoE) } 70 \mathrm{~g} / \text { ha just after } 2^{\text {nd }} \\
\text { cutting }\end{array}$ & $6.42(40.67)$ & $8.48(71.33)$ & $10.83(117.00)$ & $11.58(133.67)$ \\
\hline $\begin{array}{c}\text { T9-Sodium acifluorfen } 16.5 \% \text { + Clodinafop-Propargyl 8\% (ready mix) (PoE) } 187.5 \\
\text { g/ha just after } 1^{\text {st }} \text { cutting }\end{array}$ & $6.18(37.67)$ & $8.84(78.33)$ & $5.28(27.33)$ & $5.70(32.00)$ \\
\hline $\mathrm{T}_{10}$-Control & $6.52(42.00)$ & $9.02(81.00)$ & $10.75(115.00)$ & $12.27(150.00)$ \\
\hline S.Em \pm & 0.21 & 0.26 & 0.32 & 0.35 \\
\hline $\mathrm{CD}(\mathrm{P}=0.05)$ & 0.64 & 0.80 & 0.95 & 0.99 \\
\hline
\end{tabular}

Note* Data in parenthesis are pre transformed original values, which were transformed to $(x+0.5)^{\wedge} 0.5$ and analysed statistically

Table 2: Total weed dry weight during different growth periods of berseem as influenced by different herbicidal treatments

\begin{tabular}{|c|c|c|c|c|}
\hline \multirow[b]{2}{*}{ Treatment } & \multicolumn{4}{|c|}{ Weed dry weight $\left(\mathrm{g} / \mathrm{m}^{2}\right)$} \\
\hline & At 20 DAS & $\begin{array}{l}\text { Before } 1^{\text {st }} \text { cut } \\
\text { (55 DAS })\end{array}$ & $\begin{array}{l}\text { Before } 2^{\text {nd }} \text { cut } \\
\text { (85 DAS })\end{array}$ & $\begin{array}{l}\text { At harvest } \\
\text { (155 DAS) }\end{array}$ \\
\hline $\mathrm{T}_{1}$-Pendimethalin (PE) $1000 \mathrm{~g} / \mathrm{ha}$ & $2.37(5.15)$ & $4.92(23.78)$ & $7.78(60.00)$ & $10.75(115.16)$ \\
\hline $\mathrm{T}_{2}$ - Pendimethalin $(\mathrm{EPoE}) 1000 \mathrm{~g} / \mathrm{ha}$ at $10 \mathrm{DAS}$ & $2.49(5.68)$ & $4.92(24.66)$ & $8.14(65.76)$ & $11.30(127.21)$ \\
\hline $\mathrm{T}_{3}$-Oxyfluorfen (PE) $250 \mathrm{~g} / \mathrm{ha}$ & $1.89(3.09)$ & $4.25(17.53)$ & $7.30(52.73)$ & $10.27(104.89)$ \\
\hline $\mathrm{T}_{4}$-Imazethapyr $(\mathrm{PoE}) 40 \mathrm{~g} / \mathrm{ha}$ just after $1^{\text {st }}$ cutting & $3.21(9.81)$ & $6.23(38.30)$ & $8.98(80.16)$ & $12.51(156.00)$ \\
\hline T5-Imazethapyr (PoE) $40 \mathrm{~g} / \mathrm{ha}$ just after $2^{\text {nd }}$ cutting & $\begin{array}{c}3.27 \\
(10.14)\end{array}$ & $6.31(39.32)$ & $10.20(103.73)$ & $12.73(161.48)$ \\
\hline $\mathrm{T}_{6}$-Imazethapyr (PoE) $40 \mathrm{~g} / \mathrm{ha}$ just after $1^{\text {st }}$ cutting $f b$ Imazethapyr just after $2^{\text {nd }}$ cutting & $3.22(9.86)$ & $6.26(38.27)$ & $8.78(76.66)$ & $10.16(102.67)$ \\
\hline T7-Imazamox 35\% + Imazethapyr 35\% (ready mix) (PoE) $70 \mathrm{~g} /$ ha just after $1^{\text {st }}$ cutting & $3.13(9.30)$ & $6.28(39.00)$ & $8.24(67.33)$ & $11.44(130.26)$ \\
\hline $\begin{array}{c}\text { T8-Imazamox } 35 \% \text { + Imazethapyr } 35 \% \text { (ready mix) (PoE) } 70 \mathrm{~g} / \text { ha just after } 2^{\text {nd }} \\
\text { cutting }\end{array}$ & $3.08(9.00)$ & $6.27(38.82)$ & $10.18(103.08)$ & $12.17(147.67)$ \\
\hline $\begin{array}{c}\text { T9-Sodium acifluorfen } 16.5 \%+\text { Clodinafop-Propargyl } 8 \% \text { (ready mix) (PoE) } 187.5 \\
\text { g/ha just after } 1^{\text {st }} \text { cutting }\end{array}$ & $\begin{array}{c}3.27 \\
(10.21) \\
\end{array}$ & $6.33(39.43)$ & $4.01(15.57)$ & $6.87(46.71)$ \\
\hline T10-Control & $\begin{array}{c}3.31 \\
(10.52)\end{array}$ & $6.36(40.59)$ & $10.34(106.33)$ & $14.09(198.03)$ \\
\hline S.Em \pm & 0.15 & 0.22 & 0.36 & 0.40 \\
\hline $\mathrm{CD}(\mathrm{P}=0.05)$ & 0.46 & 0.66 & 1.07 & 1.19 \\
\hline
\end{tabular}

Note* Data in parenthesis are pre transformed original values, which were transformed to $(x+0.5)^{\wedge} 0.5$ and analysed statistically 
Table 3: Weed control efficiency during different crop growth periods of berseem as influenced by different herbicide treatments

\begin{tabular}{|c|c|c|c|c|}
\hline \multirow[b]{2}{*}{ Treatment } & \multicolumn{4}{|c|}{ Weed control efficiency (\%) } \\
\hline & $\begin{array}{l}\text { AT } \\
\text { 20 DAS }\end{array}$ & \begin{tabular}{|c|}
$\begin{array}{c}\text { Before } 1^{\text {st }} \text { cut } \\
\text { (55 DAS) }\end{array}$ \\
\end{tabular} & $\begin{array}{c}\text { Before } 2^{\text {nd }} \text { cut } \\
\text { (85 DAS) }\end{array}$ & $\begin{array}{l}\text { At harvest } \\
\text { (155 DAS) }\end{array}$ \\
\hline T1-Pendimethalin (PE) $1000 \mathrm{~g} / \mathrm{ha}$ & 51.05 & \begin{tabular}{|l|l}
41.41 \\
\end{tabular} & 38.76 & 37.31 \\
\hline $\mathrm{T}_{2-}$ Pendimethalin (EPoE) $1000 \mathrm{~g} / \mathrm{ha}$ at $10 \mathrm{DAS}$ & 46.01 & 39.25 & 37.21 & 35.75 \\
\hline $\mathrm{T}_{3}$-Oxyfluorfen (PE) $250 \mathrm{~g} / \mathrm{ha}$ & 70.66 & 56.81 & 50.41 & 47.03 \\
\hline $\mathrm{T}_{4}$-Imazethapyr (PoE) $40 \mathrm{~g} / \mathrm{ha}$ just after $1^{\text {st }}$ cutting & 6.78 & 5.63 & 24.62 & 21.21 \\
\hline T5-Imazethapyr (PoE) $40 \mathrm{~g} /$ ha just after $2^{\text {nd }}$ cutting & 3.61 & 3.12 & 2.45 & 18.44 \\
\hline $\mathrm{T}_{6}$-Imazethapyr (PoE) $40 \mathrm{~g} / \mathrm{ha}$ just after $1^{\text {st }}$ cutting $f b$ Imazethapyr just after $2^{\text {nd }}$ cutting & 6.24 & 5.72 & 27.90 & 48.15 \\
\hline $\mathrm{T}_{7}$-Imazamox $35 \%$ + Imazethapyr $35 \%$ (ready $\left.\mathrm{mix}\right)(\mathrm{PoE}) 70 \mathrm{~g} / \mathrm{ha}$ just after $1^{\text {st }}$ cutting & 11.63 & 3.92 & 36.68 & 34.21 \\
\hline T8-Imazamox 35\% + Imazethapyr 35\% (ready mix) (PoE) $70 \mathrm{~g} / \mathrm{ha}$ just after $2^{\text {nd }}$ cutting & 14.48 & 4.37 & 3.06 & 25.42 \\
\hline 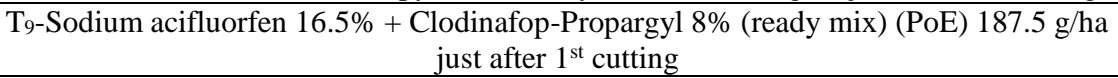 & 2.98 & 2.86 & 85.36 & 76.41 \\
\hline $\mathrm{T}_{10}$-Control & --- & --- & --- & --- \\
\hline
\end{tabular}

\section{Conclusion}

The results of the experiment revealed that PE application of oxyfluorfen $250 \mathrm{~g} / \mathrm{ha}$ found superior over rest of the treatments, as total weed density and dry weight of weeds were found significantly lowest at 20 DAS and before $1^{\text {st }}$ cutting of berseem. However, before $2^{\text {nd }}$ cutting and at harvest of berseem, total weed density and dry weight of weeds were found lowest under treatment sodium acifluorfen $16.5 \%+$ clodinafop-propargyl 8\% (ready mix) (PoE) $187.5 \mathrm{~g} / \mathrm{ha}$ just after $1^{\text {st }}$ cutting, but it was also found phytotoxic effect on berseem crop up to 15-20 DAA, hence negative impact on the growth and yield of berseem plants was observed. So it is not advisable for weed management in berseem crop.

\section{Acknowledgement}

The authors feel privileged to thank to Dr. Nitish Tiwari, Scientist, Department of Agronomy I.G.K.V., Raipur (C.G.), for his continuous help, support and guidance throughout this research work.

\section{Reference}

1. Alfred S. Evaluation of herbicides for weed management in berseem (Trifolium alexandrinum L.) M.Sc. Thesis. Submitted to Govind Ballabh Pant University of Agriculture and Technology, Pantnagar 2012, 98.

2. Anonymous. Handbook of Agriculture published by Indian Council of Agricultural Research, New Delhi 2012, 1346.

3. Jain KK. Floristic composition of berseem-weed ecosystem on weeds dynamics. Journal of World Weeds 1998;5:3739.

4. Joshi YP, Bhilare RL. Weed management in berseem (Trifolium alexandrinum L.) Pantnagar Journal of Research 2006;4(1):15-17.

5. Kewat ML, Tamrakar MK, Agrawal SB, Shukla VK. Efficacy of herbicides against Cichorium intybus in berseem (Trifolium alexandrium L.). Indian Journal of Weed Science 2002;34(3,4):333-334.

6. Mani VS, Pandita ML, Gautam KC, Bhagwandas. Weed killing chemicals in potato cultivation. Indian farming 1973;23:7-13.

7. Sharma VV, Murdia PC. Utilization of berseem hay by ruminants. Journal of Agricultural Sciences 1974;83:289293. 